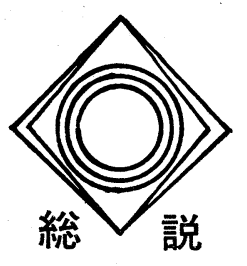

\title{
石油需給の現状と将来
}

\author{
-1983. 1. 31 受理一
}

(財)日本エネルギー経済研究所 高 垣 節 夫

\section{1. 減少続く最近の石油需要}

昭和58年度の石油製品 (然料油) 需要は, 1 億 8,500 万k程度に終る見通しである。これは，年度当初に決 められた供給計画での 1 億 9 , 204万k $\mathrm{k}$ より 700万k少な く,また 9 月に改訂された見直し数字の 1 億 8,624 万 $\mathrm{k} \ell$ よ 100 万k妙ない。当初計画の過大見積りは, 基 本になる経済計画が経済成長を高目に見積っているこ とに和もな原因があった。見直し数字がな拈過大であ ったのは，暖冬と景気低迷の長期化が理由であった (表 1)。

表 1 最近 2 年間の石油製品需要動向（単位 $1,000 \mathrm{k} \ell$ )

\begin{tabular}{|c|c|c|c|c|c|}
\hline & \multirow{2}{*}{ 56年度(A) } & \multicolumn{2}{|c|}{ 57年度 } & \multirow{2}{*}{$\begin{array}{l}\mathrm{C} / \mathrm{A} \\
(\%)\end{array}$} & \multirow{2}{*}{$\begin{array}{c}\mathrm{C} / \mathrm{B} \\
(\%)\end{array}$} \\
\hline & & 供給計画(B) & 供給改訂(C) & & \\
\hline ガソリン & 35,286 & 35,938 & 35,873 & +1.7 & -0.2 \\
\hline ナ フ サ & 23,071 & 22,679 & 21,549 & -6.6 & -5.0 \\
\hline ジェット油 & 2,855 & 2,665 & 2,775 & -2.8 & +4.1 \\
\hline 灯油 & 23,637 & 23,923 & 23,705 & +0.3 & -1.0 \\
\hline 軽 & 21,774 & 22,175 & 22,101 & +1.5 & -0.3 \\
\hline A 重 油 & 20,135 & 19,097 & & & \\
\hline B 重 油 & 3,930 & 3,056 & & & \\
\hline C 重 油 & 63,280 & 62,510 & & & \\
\hline 重 油 計 & 87,885 & 84,663 & 80,244 & $-8,7$ & -5.2 \\
\hline 燃料油計 & 194,508 & 192,043 & 186,247 & -4.2 & -3.0 \\
\hline
\end{tabular}

このように，計画の狂いはそれぞれに理由のあるこ とであり，一概にとがめられないが，問題は将来につ いて，いつまでも不確かな見通しを樹てつづけると， 関係者の信頼を損うと同時に, 石油産業自身にとって る経営計画の確かな指標が得られないことになる。そ らした難点を是正する意味からも, 石油需給の現状と 将来について再検討することは有意義である。

まず，手掛りとして油種別の需要動向を見ると，増 加したのはわずかにガソリンと軽油のみ（表 2 )。いず れも内燃機用である。これらは目下のところ, 競争商 品のない独占品種といってよい。しかし, 独占品種で ありながら，増加率は $1 \%$ 以下というところに目下の 石油不況の深刻さが現われている。自動車登録台数は 増え, 貨物輸送は鉄道からトラックの道路輸送に切り

理事 港区虎ノ門1-18-1 第10森ビル
替えられつつあるにもかかわらず，自動車の小型化， 省然料化が進行して，ガソリン消費の伸びを抑えてい

表 2 暦年ベースで見た前年比石油製品需要

\begin{tabular}{|c|c|c|c|c|c|c|}
\hline & & 年 & 年 & 増 & 減 & 兽減率 \\
\hline ソ リ & ン & & & + & 198 & +0 \\
\hline ナ & サ & & & - & 2008 & -8 \\
\hline$\ddot{~} ェ ッ ト$ & 油 & 2 & & - & 43 & -1 \\
\hline . & 油 & 2 & & - & 2185 & -8 \\
\hline 軽 & 油 & & & + & 114 & +0. \\
\hline 重 & 油 & & & - & 1362 & -6. \\
\hline 重 & 油 & 017 & & - & 1329 & -30 \\
\hline 重 & 油 & 0 & 6 & - & 7246 & -11 \\
\hline 1 & & & & & & \\
\hline
\end{tabular}

（注） 昭和57年は通産省の速報ベース 
表 3 家庭用燃料の価格比較

\begin{tabular}{|c|c|c|c|c|c|c|c|c|c|}
\hline & \multirow{2}{*}{ 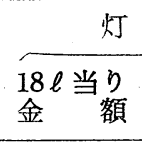 } & \multirow{2}{*}{$\underbrace{\text { 油 }}_{\text {円 } / 1000 \mathrm{kcal}}$} & \multicolumn{2}{|c|}{ L P G } & \multicolumn{2}{|c|}{ 都 市ガ ス } & \multirow{2}{*}{$\frac{\text { 電 }}{\text { 月間支払 }}$} & \multirow{2}{*}{$\frac{\text { 気 }}{\text { 円 } / 1000 \mathrm{kcal}}$} \\
\hline & & & & 円 $/ 10 \mathrm{~m}^{3}$ & 円/1000kcal & $\begin{array}{l}\text { 月間支払 } \\
\text { 額 (円) }\end{array}$ & 円 $/ 1000 \mathrm{kcal}$ & & \\
\hline 札 & 幌 & 1,754 & 10.95 & 5,632 & 22.62 & 3,913 & 21.27 & 5,260 & 34.95 \\
\hline 仙 & 台 & 1,778 & 11.10 & 5,169 & 20.76 & 5,400 & 15.85 & 5,377 & 33.43 \\
\hline 東 & 京 & 1,834 & 11.45 & 4,919 & 19.76 & 5,687 & 16.01 & 5,198 & 32.15 \\
\hline 名 古 & 屋 & 1,813 & 11.32 & 4,830 & 19.40 & 6,015 & 18.97 & 5,087 & 31.63 \\
\hline 大 & 阪 & 1,829 & 11.42 & 4,917 & 19.75 & 5,831 & 17.03 & 5,326 & 29.92 \\
\hline 広 & 島 & 1,851 & 11.55 & 4,964 & 19.94 & 4,482 & 19.21 & 5,269 & 32.08 \\
\hline 高 & 松 & 1,834 & 11.45 & 4,739 & 19.03 & 3,769 & 17.69 & 4,883 & 30.36 \\
\hline 福 & 岡 & 1,854 & 11.57 & 4,998 & 20.08 & 5,900 & 21.84 & 5,248 & 32.45 \\
\hline 全国平 & & 1,825 & 11.39 & 4,976 & 19.99 & & 16.99 & & 31.88 \\
\hline
\end{tabular}

（注）灯油, L P Gは通産省モニター調查。灯油は, $8,900 \mathrm{kcal} / 18 \ell, L$ P Gは $12,000 \mathrm{kcal} / \mathrm{kg}$ で計算。 ガス, 電気は, 各社料金規程により, 1 世帯当りの平均消費実績により算出。ガスの $1 \mathrm{~m}^{3}$ 当り発熱 量は, 東京, 大阪, 名古屋が $11,000 \mathrm{kcal} / \mathrm{m}^{3}$, 札幌, 仙台が $5,000 \mathrm{kcal} / \mathrm{m}^{3}$, 広島, 高松, 福岡が $4,500 \mathrm{kcal} / \mathrm{m}^{3}$ 。調査時点は昭和 52 年 11 月。計算は石油情報センター。

る。貨物輸送の面では, 国鉄貨物駅の廃止が進む一方, トラック輸送は小口宅配便に至るまで活動範囲をひろ げているが，景気低迷による貨物輸送量全般の不振の 方が大きくひびいて，軽油需要の伸びを小幅なものに している。

これに対して需要不振の油種は軒並みで, しかる需 要隇の理由の根が深い。いわゆる構造的なもので石油 需要の拡大・再活性化には，よほど思いきった対策が とられねばならないと判断される。

たとえば，需要堅調と期待された中間三品のひとつ である灯油需要は，暦年ベースで見ると，昭和57年は 前年比 $8.9 \%$ も減少しているが，これが単純に暖冬の せいだと言い切れるかといらと，都市ガス，電気から の競争圧力が見逃せなくなっているよらである(表3)。 すなわち，ひとつには灯油価格の上昇により，カロリ 一当り単価が接近したこと。2つには，電気によるヒ 一トポンプの出現が家庭用冷暖房のあり方に変化を起 こしつつあることがあげられる。カロリー当り単価と いう点では，とりわけLNG（原油よりカロリー当り 単価は安い) をべースにした, 東京, 大阪, 名古屋 (東 邦ガス) など大都市圈では, かつての灯油 1 対ガス 2.5 3.0 という比価の関係が，今では計算のしかた （例，ガス税を加えるかどうかなど）によっては1対 1.3 を切り，1.27 といら際どいところまで接近してき ている（表 4)。電気によるヒートポンプは，台数の上 ではまだ小規模だが，手軽さ，安全性などの利点が消 費者の関心を集めれば，将来は関東以西の比較的温暖 な地区では，かなりの普及度を示すかる知れない。灯
油は都市ガス, 電気からの競争圧力により, 北海道, 東北 (それも青森を含む主として日本海寄りの地域) 地方など，極寒地帯での主力燃料といらことになって ゆく可能性がある。現に小型石油ストーブの生産・販 売量の激減は，そうした将来を暗示するるのがある。

\section{2. 影響大きい発電用燃料市場動向}

需要減退の最大のものは, いうまでもなくC重油で あり,とりわけ発電用の重油である。

石油需要の規模 (総量) は発電用燃料の今後のあり 方によって決まるだろらということは，すでに指摘し てきたところであるが，この予見は単にカロリー当り 比価による燃料選択の問題としてばかりでなく, 最近 は景気の低迷, 電力需要, とりわけ産業用大口需要の 不振によって，一段ときびしいものになりつつある。

ひとつの試算によれば，昭和58年度の電力需要は, 4,782 億 $\mathrm{kWh}$ と, 昭和 57 年度の予想数値 $(4,698$ 億

表 4 家庭用燃料の比価（灯油 $=1.00 ）$

\begin{tabular}{|c|c|c|c|c|c|}
\hline & & 灯油 & L P G & 都市ガス & 電気 \\
\hline 札 & 幌 & 1.00 & 2.07 & 1.94 & 3.19 \\
\hline 仙 & 台 & 1.00 & 1.87 & 1.43 & 3.01 \\
\hline 東 & 京 & 1.00 & 1.73 & 1.40 & 2.81 \\
\hline 名 古 & 屋 & 1.00 & 1.71 & 1.68 & 2.79 \\
\hline 大 & 阪 & 1.00 & 1.73 & 1.49 & 2.62 \\
\hline 広 & 島 & 1.00 & 1.73 & 1.66 & 2.78 \\
\hline 高 & 松 & 1.00 & 1.66 & 1.54 & 2.65 \\
\hline 福 & 岡 & 1.00 & 1.74 & 1.89 & 2.80 \\
\hline 全国平 & & 1.00 & 1.76 & 1.49 & 2.80 \\
\hline
\end{tabular}


表 5 最近の電力需要の実績と予想

(単位 100 万 $\mathrm{kWh}$ )

\begin{tabular}{cccc}
\hline & $\begin{array}{c}\text { 昭和56年度 } \\
\text { 実 績 }\end{array}$ & $\begin{array}{c}\text { 昭和57年度 } \\
\text { 推 定 }\end{array}$ & $\begin{array}{c}\text { 昭和58年度 } \\
\text { 予 想 }\end{array}$ \\
\hline 電 . 灯 & 110,295 & 112,300 & 117,440 \\
電 力 & 360,266 & 357,500 & 360,800 \\
（計大口） & $(212,323)$ & $(206,400)$ & $(203,000)$ \\
合. 計 & 470,561 & 469,800 & 478,200 \\
\hline
\end{tabular}

（出所） セキッゥ，昭和58年 1 月 1 日号より。

$\mathrm{kWh}$ の $1.8 \%$ 増でしかなく（表 5 ），これに対応する 発電源は, 最近の 原子力の 高稼働率を前提にし, ま た，長期硬直的な L NGの輸入契約の実状からみて， 火力発電量は 3,400 億 $\mathrm{kWh}$ と, 僅かながら前年 (昭和 57 年度予想は 3,417 億 $\mathrm{kWh}$ ）を下回るということにな って拉り（表 6 ), この小さくなったパイ（火力発電総 量）の中で, 石炭火力と石油系火力がどのようなシェ アーを与兄られるかが今後の問題であるが，燃料コス トの観点だけからすれば，石炭価格が上昇気味とはい うものの, まだ石油は石炭より割高である。このため, 原油生楚きをかなり減らしても, 昭和58年度の発電用 重油は，前年より 380 万k $\ell$ (12\%強) も減るという試 算結果となっている(表6下段)。

以上はあくまでひとつの試算でしかないが,しかし， 方向としては十分あり得る想定といわねばならない。 とくに，LNGはかつての電力需要高度成長期に大量 の契約がなされ, 昭和58年度以降, 徐々飞契約は実施 段階に入る。take or pay 方式の契約であるだけに， 引き取り量の調整はきわめて小幅なるのでしかない。 コンスタントな引き取りを前提とするこの契約方式 上，LNGはベース・ロード用に使われるのが常であ
るが，もし電力需要が伸び悩めば，同じくベース・ロ ード用の原子力発電を競合する可能性もなくはない。 この LNG医ど強力ではないが, 石炭（海外）の開 発プロジェクトもかなり問題である。海外開発プロジ ェクトを約束通り（たとえば長期エネルギー計画で揭 げた一般炭の輸入量のような）大規模に引き取れば, 重油需要は大削減となるだろう。逆に重油需要を計算 通り減らせないとなれば，今度は海外炭開発プロジェ クトを延期もしくはキャンセルせざるを得なくなるだ ろう。現実は後者, つまり重油需要は極力温存して, 海外炭開発の延期へと向かいつつある。国際的波紋が 懸念される所以である。

しかし，懸念してみてもそれだけで解決になるわけ ではない。それどころか, 中曾根新内閣によって, 長 期の経済計画は $3 \sim 4 \%$ 経済成長率が見込まれるこ とになりそうである。電力需要の成長速度も，従来の $4 \%$ 台から $3 \%$ 台に落ちる可能性が強い。これを電源 開発, 燃料入手対策の年次計画淔すと, 電源開発 規模は $5 \sim 7$ 年の遅れ。火力発電用燃料計画の場合に は, 注とんぞ新規の追加燃料は必要でなくなるか子知 れない。現実には、「招かれざる客」の新規・追加然料 が入着する度合だけ, 既存の重油燃料市場は狭められ てゆくといら長期のシナリオが浮んでくるのである。

\section{3. アメリカの燃料市場動向とO P E C の}

\section{対応}

わが国の石油製品需要動向は，以上からわかるよう に，ガソリン，軽油などの反騰力はきわめて微弱であ り, 期待の中間 3 品も灯油，A重油が以外なるでに不 振。残るナフサ，C重油などの産業用品種は，ナフサ はドン底の状態で下げ止まり，C重油は電力用でまだ 下がり続けるとなると，全体としては，まだ減少が続

表 6 最近の電力供給と発電用燃料の内訳 (100万kWh)

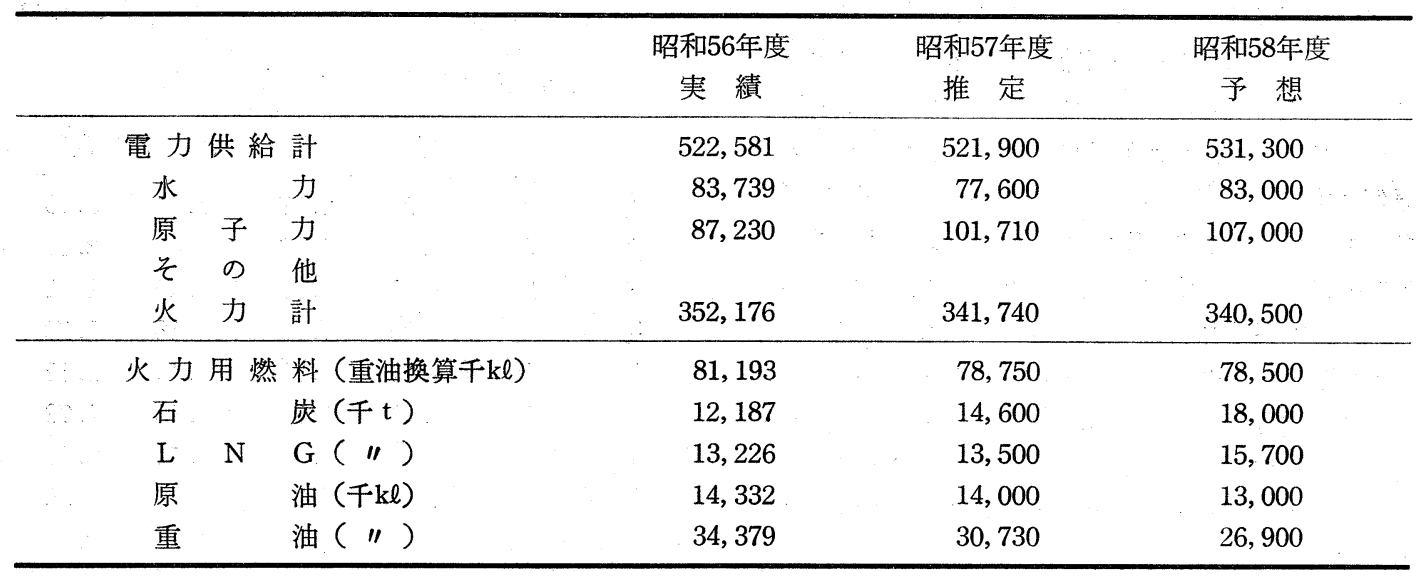


表 7 第 2 次オイルショック前後でみた アメリカの然料消費動向比較

(単位 $10^{15} \mathrm{BTU}$ )

\begin{tabular}{lrr}
\hline & 1978 年 & 1981 年 \\
\hline (エネルギー消費) & 78,175 & 73,965 \\
石 炭 & 13,846 & 16,109 \\
天然ガス & 20,000 & 19,762 \\
石 油 & 37,965 & 32,113 \\
水 カ & 3,141 & 2,970 \\
原子力 & 3,024 & 2,901 \\
\hline
\end{tabular}

(発電用燃料)

石炭 (千 $\mathrm{t})$

$481,235 \quad 596,797$

天然ガス（10億立方フィート） $3,188 \quad 3,640$

石 油 (100万bbl) $\quad 635 \quad 351$

(出所) アメリカ DOE「Monthly Energy Review」各月号

く可能性が強い。石油業界には, 次に述べる原油高值 是正の気運と相まって, 近く需要は下げ止まるとの期 待が強いが，それは目下のところ，あくまで期待であ り，現実は決して楽観を許さない。

そのことは, アメリカの燃料市場にも同じ兆候が現 われて拈り, 石油需要減の大半が発電用重油の減少に よっているのを示している（表 7)。これる本誌ですで に指摘したことであるが, 自由世界の発電用石油消費 は, かつて 400万bbl/d に達したことがあり, これが 最近までに半減近くになっている。このまま推移すれ ば, 発電用石油需要はきわめて限られたものになり, O P E CKとっては, 日産 $1,500 〜 1,600$ 万bl という 状態に生産を固定化される怙とれがなしとしない。
OPECにとっても, 世界の石油企業にとっても, こ の状態は決して好ましいものではない。新しい動きが 出るのは確実視されるのが最近の実状である。

OPE C 原油の価格が，どのような結末を辿るか は，産油国間の意見対立，とりわけイラン・イラク戦 争の賠償が絡み, さらにその背景には, サウジアラビ アの主導権に挑戦するイランその他の産油国, といら 複雑な関係が重なり合っているため，その行方を断定 するのは困難である。

しかし，経済的な実勢だけからすれば，OP E C 原 油価格の突出ぶりは明らかである。表 8 に示されてい るように，自由化されているアメリカ市場では，サウ ジアラビアの原油は英国北海原油に対して, 約 1 ドル 50セント, イランにくらべて 3 ドル, メキシュ, カナ ダ, ベネズェラなどの南北米大陸諸国にいたっては10 ドルもの差がついている。無論品質差を考虑する必要 はあるが，中東諸国の割高さには変わりない。

サウジアラビアの原油は, この結果, アメリカ市場 では存続できなくなろうとしている。事実，1982年12 月のサウジフラビア原油の対米輸出量は 40 万bl/d を 割っている。

こうした動きが, 中東原油価格引き下げを導き出す ための演出効果だとする見方がある。それほど，OP E C 内部の意思決定は柔軟性を欠いている，という見 方である。真偽は別として，事態が中東原油価格が值 下げへ向からのを必至とさせているのは否定できな い。

仮りに，中東原油が值下りすると，どらいう影響が 出るかだが, 先に触れたアメリカ国内での発電用燃料 市場ではかなりの程度, 重油が天然ガスに対して競争

表 8 アメリカ市場における原産地別原油の入着価格と数量

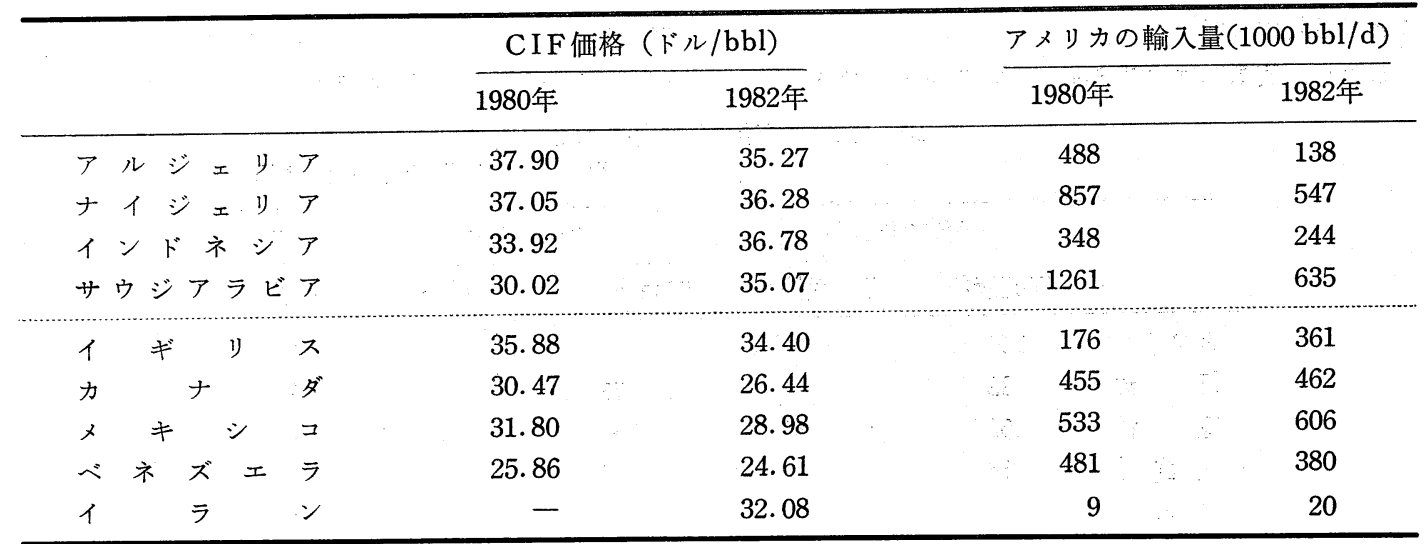

(出所) DOE「Monthly Energy Review」各月号 
表 9 アメリカの発電用燃料の価格差接近状況 (セント/100万BTU)

\begin{tabular}{lcccc}
\hline 年 & 重 油 & 天然ガス & 石 炭 & 燃料平均 \\
\hline 1978 & 212.3 & 143.8 & 111.6 & 139.3 \\
1979 & 299.7 & 175.4 & 122.4 & 162.1 \\
1980 & 427.9 & 221.4 & 135.1 & 190.4 \\
1981 & 529.4 & 282.5 & 153.2 & 222.5 \\
1982 •8月 & 458.8 & 355.7 & 164.7 & 224.7 \\
\hline
\end{tabular}

(出所) DOE「Monthly Energy Review」各号

力を回復するものと見られる（表 9 ）。

わが国の場合, 単純に価格比較だけから結論づけら れないが，しかし仮りに原油，それにつれて重油が値 下りするようであれば，重油対海外輸入炭の競合関係 は，微妙に変化することにならう。すなわち，従来の 重油に対する海外炭の圧倒的有利さは消光て, 両者の 価格競争力はほぼ均衡することになろう。実際には， 電力需要の純化で, 過大に見積もられた発電用燃料の 購入計画が修正されつつあり, 海外炭は未着手の開発 プロジェクトが多いだけに，廃止，延期が続出してい る。つまり，この場合は，コスト比較による選択とい らより，絶対的供給過剩から，舞台に登場する以前に 疎外されたわけである。

\section{4. 需要維持, 拡大のための石油製品価格体系}

わが国の将来の石油需要を考える上で，見忘られが ちなのは，他種燃料との比較の上で，品種別にどのよ らな増減をたどるか，といらことである。

従来からも，そうした経済的比較の作業がなかった わけではないが，概して，ナフサ，C重油は海外の天 然ガス，石炭にくらべて競争力が無く，これに反しガ ソリン，灯油，軽油，A重油は需要堅調で，いわゆる 「白もの不足」あるいは，中間 3 品の不足対策といら ことで定説化していた。

しかし，実際には中間 3 品のうちのひとつである灯
油需要が伸び悩んでいるのに現われているょうにこ れら品種といえども，必ずしも独走的に需要が伸びて いるわけではない。都市ガス, 電気からの競争圧力は, 石油製品価格全般の上昇の中で，かなりり程度高まっ ている。

石油製品の卸売価格の動向はこうした市場での競争 関係を反映して, 昭和57年以来, 微妙に変化している。 C重油価格は昭和56年から昭和57年にかけてほとんど 上昇していない。石炭にくらべて割高であると同時 飞，別の見方をすれば，注ぼ原油と等価といら関係で 釷づけにされていると見ることもできる。中間 3 品の らち，A重油は需要不振加ら，大きく上昇していない。 灯油・軽油にいたって，漸やく, $1 \mathrm{k}$ 当り 5,000 円の上 昇，ガソリンは最も大幅な 10,000 円 $/ \mathrm{k} \ell$ の值上りであ る(表10)。

この動きは，いうまでもなく白物中心の急傾斜の価 格体系へと移行しつつあるのを示している。全体とし ては市場動向を反映したるのであり，原油価格上昇の 負担が石油消費者各層に分散されつつあるのが示され ている。これは昭和54年以来，行政指導により，石油 製品価格が原油の頻繁な上昇に応じて，一律に原油価 格上昇分だけ同額の值上げで硬直的に推移してきた当 時とくらべて，市場の動向を反映したものへ変わりつ つあるのを示している。

実際には，この価格体系の変化をもってしても，ま だ将来の石油産業のあり方に，十分明るい展望を約束 したものにはなっていない。具体的には，物量的な製 品バランスからい总ば，過剩気味のC重油を分解（重 質油分解）して，不足気味の中間 3 品に転換すること が必要になりつつあるが，採算的には前記の製品価格 体系では，そうした操作が難しい。つまり前出表10で 見ると，C重油と灯油・軽油の值開きは，1k当り 2 万3,000円でしかないが，重質油分解のコストは，1kl 当り 30,000 35,000円と推定される。したがって，重

表 10 最近の石油製品価格体系の変化

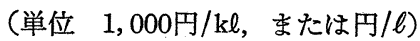

\begin{tabular}{|c|c|c|c|c|c|}
\hline & \multicolumn{2}{|c|}{ 昭和 57 年 12 月 } & \multicolumn{2}{|c|}{ 昭和56年12月 } & \multirow{2}{*}{$\begin{array}{l}\text { 上昇幅 } \\
\text { (税抜き) }\end{array}$} \\
\hline & 卸売価格 & 同, 税抜き & 卸売価格 & 同, 税抜き & \\
\hline ガソリン & 155 & (101) & 145 & (91) & +10 \\
\hline 灯 & 82 & & 77 & & +5 \\
\hline 軽 油 & 106 & $(82)$ & 101 & (77) & +5 \\
\hline $\mathrm{A}$ 重 油 & 76 & & 75 & & +1 \\
\hline $\mathrm{C}$ 重油 & 59 & & 57 & & +2 \\
\hline
\end{tabular}

（注）出所：日経商品市況。特約店向 $45 \sim 90$ 日 手形払いの条件。 
質油分解を経済的に成り立たせるためには，灯油・軽 油価格は現状よりさらに $1 \mathrm{kl}$ 当り 10,000 円程度の上昇 が必要となる。しかし，市場では現段階ですら1当り

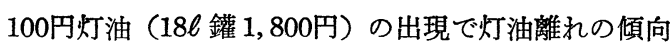
が出ている。これにさらに1靑上乗せがあったと

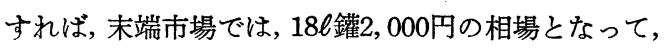
他の家庭用燃料市場を亘食される危険が大きい。と すると, 必要経費が賄えない限り, 重質油分解は成立 乙難くなり，石油製品需給は引き続き重油過剩，中間 製品不足の傾向が続き，また，石油製品需要総量はシ リジリと減少が続くという最悪の事態になりかねな W。

もしこの窮状を救う手段があるとすれば，近く必至 と見られる原油の值下りに際して，その值下り分をそ のま重油価格の值下げに見合わせ，一方で重油需要 の喚起（実際には下げ止まりというべきかる知れない が）を期待すると共に, 重質油分解によって, 中間 3 品の不足を緩和するといらコースである。

どの程度の原油値下り，そして前記の説明からすれ ば, 即, 重油の值下りということになるが, その值下げ 幅はどのくらいであればよいかといえば，先の灯油， 軽油価格飞見合って，重質油分解に経済性を持たせる となると，k当り10,000円という大幅なるのとなる。 最近の 1 ドル230〜240円の為替相場を前提にすると， $1 \mathrm{bbl} 6.60 \sim 6.90$ ドルの值下げが 必要となる。中東の
基準原油価格は, $1 \mathrm{bbl} 28$ ドル 見当への 是正というこ とになる。

2 回にわたるオイルショックで「中東, あるいは OPECの原油価格は上るもの」と固く信じ込まれて いる向きには，これは夢物語りのように聞こ党るかも 知れない。しかし, 一挙に $1 \mathrm{bbl} 28$ ドルの価格が 実現 するかどうかは別として, 今後の事態の発展は抢そら くそれに近いところへ進んでゆくだろう。近く予想さ れる中東原油の名目価格の引き下げに, 支払猶予期間 の延長その他を加えて, 実質価格は下方修正の動きが 必至である。

このことは，わが国の石油産業にとって起死回生の 機会をもたらすだろう。無論, 影響はわが国に対して ばかりではない。むしろ, アメリカに打ける変化の方 が大きいかも知れないし, 中東原油価格引き下げ圧力 自体も本稿で度々引用したように, アメリカ市場での 競争が原因となっている面が多い。また，見方を变光 れば，OPEC原油の行き過ぎた上昇の結果, メジャ 一の収益が急減しているのも, 根はひとつであるとい えよう。

こうした世界を挙げての石油関係者の苦境は, なん としても打開されねばならぬものである。との一環に わが国の石油産業がある。最近数年間の極度の不振か ら立直る機会をどう読み, どう対処するかが今後の課 題である。 


\title{
The Demand and Supply Balance of Petroleum Products at Present and in the Future
}

\author{
Setsuo TAKAGAKI \\ (The Institute of Energy Economics)
}

SYNOPSIS : - The demand of petroleum products in Japan have been declining for several years. Even for the future, we cannot expect remarkable increase of petroleum products because the considerable volume of heavy fuel oil may be expelled out of the thermal power generation fuel market.

The similar situation can be observed in the U.S. fuel market, where the various source of crude oil is conducting the price-cutting competition within the shrinked market of thermal power generation market. As a result, the highly priced crude oil such as Saudi Arabian, Algerian and Indonesian oil will have to cut their prices in order to keep their market position in the U.S.

The Japanese petroleum industry will have a chance to recover its competitiveness against other fuel if only the middle east OPEC member countries should reduce their oil prices drastically. In that case, the heavy fuel oil price should be mainly reduced to recover the demand in the thermal power generation fuel market.

The Japanese petroleum industry can be revitallized only in those circumstances.

\section{Key Words}

Demand of petroleum products, Crude oil price, Thermal power generation fuel, U.S. fuel market 